\title{
Growth, Productivity and Quality of Soybean Grains, Submitted to Different Seed Treatments
}

\author{
Mádilo Lages Vieira Passos ${ }^{1}$, Lusiane de Sousa Ferreira ${ }^{1}$, Késsia Tenório Figueirinha ${ }^{1}$, \\ Jarlyson Brunno Costa Souza ${ }^{1}$, Antonio Gabriel da Costa Ferreira ${ }^{1}$, Carlos Augusto Alves Cardoso Silva ${ }^{1}$, \\ Eduardo Arouche da Silva ${ }^{1}$, Edmilson Igor Bernardo Almeida ${ }^{1}$, José Roberto Brito Freitas ${ }^{1}$ \\ \& Washington da Silva Sousa ${ }^{1}$ \\ ${ }^{1}$ Universidade Federal do Maranhão, Chapadinha, Maranhão, Brazil \\ Correspondence: Mádilo Lages Vieira Passos, Universidade Federal do Maranhão, Chapadinha, Maranhão, CEP: \\ 65500-000, Brazil. Tel: 55-989-9224-7341. E-mail: madilolages@hotmail.com
}

$\begin{array}{lc}\text { Received: March 30, } 2019 & \text { Accepted: May 18, } 2019 \quad \text { Online Published: July 31, } 2019 \\ \text { doi:10.5539/jas.v11n11p274 } & \text { URL: https://doi.org/10.5539/jas.v11n11p274 }\end{array}$

The research is financed by Agroverdes Comércio e Representação Agrícola LTDA-EPP.

\begin{abstract}
The protection conferred via chemical treatment of seeds is indispensable to the normal development of crops, with a view to the best use of its productive potential. The objective of this study was to evaluate the soybean crop response, cultivate 'FTS Paragominas RR', to seed treatment. The study was conducted in an experimental area of the Center of Agrarian and Environmental Sciences of the Federal University of Maranhão, in Chapadinha (MA), from February to June 2018. A randomized complete block design was used, with split-plot in time. The plots consisted of five seed treatments: thiophanate-methyl + fluazinam fungicides, fludioxonil, carbendazim + thiram, the insecticide fipronil and the absence of the application. Throughout the crop cycle the agronomic characteristics were verified: plant height, stem diameter, and leaf area. And, at the time of harvesting, grain yield, the height of insertion of the first pod, the total number of pods and weight of 1000 grains. Seed treatments induced very variable responses on the growth and development of soybean 'FTS Paragominas RR'. The best performances were obtained with the use of thiophanate-methyl + fluazinam fungicides (dose $198 \mathrm{~mL}$ ) and fludioxonil (dose $200 \mathrm{~mL}$ ). The application of carbendazim + thiram and fipronil, both at a dose of $200 \mathrm{~mL}$, presented adverse effects throughout the vegetative and reproductive phases of soybean 'FTS Paragominas RR'. None of the products provided significant increases in grain yield.
\end{abstract}

Keywords: Cerrado of Maranhão state, fungicide, Glycine $\max$ (L.) Merrill., insecticide, east region of Maranhão state

\section{Introduction}

The soybean [Glycine max (L.) Merrill.] has been highlighted in the Brazilian agricultural scenario, as one of the segments that has grown the most in the last three decades and is equivalent to $57 \%$ of the area planted in grains in the country. Thus, it is considered, among other crops, one of the greater economic importance of agribusiness (Peixoto et al., 2018).

The national production, in the 2017/2018 harvest, totaled 118 million tons, an increase of $3.5 \%$ compared to the 2016/2017 harvest. The area cultivated was 35.1 million hectares, resulting in mean productivity of 3.4 tons ha $^{-1}$, of which 58.4 million tons were exported, giving Brazil the leadership of world grain exports (Korber et al., 2017; Companhia Nacional de Abastecimento [CONAB], 2018).

The center-west region presents the highest contribution of total production, responsible for $46.8 \%$ of what is produced internally in $46.1 \%$ of the total explored area with soybean (Leal et al., 2015). The Northeast estimates a cultivated area of 3,264.4 thousand hectares, with the production of 11,470.8 thousand tons and mean productivity of 3,514 $\mathrm{kg} \mathrm{ha}^{-1}$ (Petter et al., 2014; CONAB, 2018). In this region, the state of Bahia excelled for its expressive production, followed by Maranhão and Piauí.

It is attributed the expansion of productivity to the technological advances, the innovations in production systems, to the development and structuring of the international market, to the consolidation of soybean as a source of 
vegetable protein and the generation of new technologies that enabled the expansion of exploration in several regions of the world (Hirakuri \& Lazzarotto, 2014; Marcon et al., 2017).

According to Artuzo et al. (2018), the growth of soybean cultivation in Brazil has always been associated with scientific advances in the productive sector and whose efficiency in the production and uniformity of the plant population is conditioned to the use of good quality seeds. Carvalho and Novembre (2011), claim that the physiological quality of the seed infers the ability to perform vital functions, such as germination, vigor, and longevity, and ensure the percentage and uniformity of seedling emergence.

In this sense, the seed treatment technique excelled as a technological tool of great importance in the protection of agriculture, to improve and maintain its quality, performing a primary role in protecting seed against pests and/or phytopathogens. This contributes to the germination and emergence processes, as well as to the development of more vigorous seedlings (Buzzerio, 2010; Balardin et al., 2011).

In seed treatments, the substances applied to them, in general, aim the denominated phytotonic effect, characterized by beneficial advantages in the growth and development of plants (Schoeninger, 2014). According to França-Neto et al. (2016), seed treatment with fungicides offers a guarantee of the better establishment of the plant population, by controlling important pathogens transmitted by seeds, reducing their introduction in indene areas.

According to Dan et al. (2010), the use of insecticides in seed treatment is also an important alternative to avoid possible losses due to the action of soil pests and the aerial part, which damage seeds and young seedlings, with losses in crop yield. Consequently, occur economic damage and posterior increase in costs for the corrective control of pests.

Although the beneficial effects of seed treatment for disease/pest control are reported, there are many unknowns about its interference in growth and production of plants, notably the soybeans, which is one of the main seed-propagated crops in the world. In Maranhão, these studies are even more scarce, regardless of the prominence that the state has won the Brazilian soybean crop.

Thus, the objective of this study was to evaluate the response of soybean cultivar 'FTS Paragominas RR' to the treatment of seeds with different fungicides and an insecticide.

\section{Material and Methods}

The study was conducted in an experimental area of the Center of Agrarian and Environmental Sciences of the Federal University of Maranhão, located in the municipality of Chapadinha, Maranhão, with a geographical coordinate of $3^{\circ} 44^{\prime} \mathrm{S}$ of latitude, $43^{\circ} 21^{\prime} \mathrm{W}$ of longitude and an average altitude of 105 meters. According to Thornthwaite, the climate is $\mathrm{C}_{2} \mathrm{~S}_{2} \mathrm{~A}^{\prime} \mathrm{a}$ ' type, in other words, sub-humid, mesothermic with marked water deficiency in the summer, average annual temperature of $27.9^{\circ} \mathrm{C}$ and annual precipitation of $1613 \mathrm{~mm}$ (Passos et al., 2016).

The predominant vegetation of the study region is of Cerrado type, with a diversified floristic composition and passing through forms such as closed, sealed, typical and dense cerrado (Instituto Brasileiro de Geografia e Estatística [IBGE], 2012). The predominant types of soils are Latosols, Argisols, Plinthosol, and Planosols (Empresa Brasileira de Pesquisa Agropecuária [EMBRAPA], 1999).

The research was developed with the cultivar 'FTS Paragominas RR', implanted in the agricultural year of 2017/2018, with sowing performed in February and the desiccation in June 2018. The cv. 'FTS Paragominas RR', created by the Company FT seeds, presents high productive potential (on average $3600 \mathrm{~kg} \mathrm{ha}^{-1}$ ), wide adaptation and stability, excellent root health and rusticity; it has a particular type of growth, height between 80 and 110 centimeters, cycle variable from 140 to 145 days, recommended for low to medium fertility soils (FTS, 2009; Reges, 2018).

The experiment was conducted in a randomized complete block design, with time subdivided in plots. The plots consisted of five treatments of seed and the subplots for three periods of different measurements. Each treatment contained four replicates, making up twenty experimental units (in the plots). The seed treatments consisted of the application of three fungicides [Thiophanate-methyl + fluazinam (dose $198 \mathrm{~mL}$ per $100 \mathrm{~kg}$ of seed), Fludioxonil (dose $200 \mathrm{~mL}$ per $100 \mathrm{~kg}$ seed) and carbendazim + thiram ( $200 \mathrm{~mL}$ per $100 \mathrm{~kg}$ seed)], an insecticide [Fipronil (dose, $200 \mathrm{~mL}$ for $100 \mathrm{~kg}$ of seeds) and control (absence of application)]. The above-mentioned doses were those recommended by the manufacturers in the package leaflet.

The seeds were treated in the Plant Ecophysiology Laboratory, where the dose of each chemical is diluted in distilled water until obtaining a homogeneous syrup that was added to the seeds in plastic bags with a capacity of 
$2 \mathrm{~kg}$. The mixture was stirred for 4 minutes to provide complete coating and uniformity of treatments on the seed mass.

At sowing, the inoculation of soybean seeds with bacteria of the genus Bradyrhizobium, from commercial liquid inoculant (formulated in a liquid medium) was performed. The inoculant presented the strains SEMIA 5079 and SEMIA 5019, which are recommended for the soybean. The experimental plots had a fixed rectangular size of $3.0 \times 4.0 \mathrm{~m}$, with a usable area composed of fourteen plants per linear meter, the line spacing of $50.0 \mathrm{~cm}$ and a total of ten lines.

Throughout the crop cycle, the following agronomic characteristics were verified: plant height (AP), stem diameter (DC) and leaf area (FA). For this purpose, 10 plants were randomly selected from each replicate of the treatments, carefully identified in contiguous rows.

The estimates of the variables were performed in periods of 35, 50 and 65 days after sowing (DAS), which featured three regular measurements spaced over a period of 15 days and ceased after 65 DAS.

Plant height $(\mathrm{cm})$ was measured using millimeter tape, given by the average distance between the soil surface and the caulinar apex. The diameter of the stem $(\mathrm{mm})$ was intermediate of digital calipers, positioned in the elevation of the cotyledon node in orientation contrary to the insertion of these. Leaf area $\left(\mathrm{cm}^{2}\right)$ was estimated by the indirect and non-destructive method, using Image ${ }^{\circledR}$ software and basic assumptions of digital image processing, whose complete functional structure is described by Henten and Bontsema (1995). The acquisition and digitalization of the foliar surface were done through a digital camera, with a maximum resolution of 14 MP. Each leaflet was fixed on the sheet of white A4 paper (contrasting surface), in which there was a rectangle graduated in centimeters, for the establishment of the conversion scale between pixel and centimeters.

After desiccation, thirty plants were harvested, at random, in the useful area of each experimental plot and, according to the treatments, were performed quantification of productivity variables (P), 1000 grain weight (PMG), height of insertion of the first pod (AIPV) and total number of pods (NTV), in the Plant Ecophysiology Laboratory of the respective campus. For statistical inferences, in this case, it considered the experimental randomized block design with 5 replications and 4 treatments composed of the arithmetic mean of thirty plants.

The grain yield $\left(\mathrm{kg} \mathrm{ha}^{-1}\right)$ was calculated through the area occupied by the harvested plants, where the total volume of grains in a precision scale was weighed and the transformed values for $\mathrm{kg} \mathrm{ha}^{-1}$. The variable height of insertion of the first pod $(\mathrm{cm})$ was measured using the tape arranged parallel to the main stem of the plant, given by the distance from the colon to the lower end of the first legume.

The total number of pods was characterized by manual counting of pods per plants, and at the end, the total amount of these was added, according to the treatments analyzed. The weight of 1000 grains (g) was obtained from the counting and separation of one thousand grains per plot, manually, with posterior weighing in a digital scale with an accuracy of $\pm 0.01 \mathrm{~g}$.

The data were submitted to the analysis of variance, with the application of the student t-test at $5 \%$ of significance, to compare the means. The statistical analyses were performed with the help of Sisvar 5.6 software (Ferreira, 2008).

\section{Results and Discussion}

According to the results of the analysis of variance, there were significant effects of seed treatments and evaluation time on plant height (AP), stem diameter (DC) and leaf area (FA). Both in individual effects and an interaction $(\mathrm{p}<0.05)($ Table 1$)$.

Table 1. Calculated F results for plant height, leaf area, and stem diameter, for soybeans submitted to different seed treatments

\begin{tabular}{llll}
\hline \multirow{2}{*}{ Sources of Variation } & \multicolumn{3}{c}{ Calculated F } \\
\cline { 2 - 4 } & Plant height & Stem Diameter & Leaf Area \\
\hline TS & $18.537^{*}$ & $28.663^{*}$ & $6.692^{*}$ \\
Time & $218.656^{*}$ & $12.128^{*}$ & $26.997^{*}$ \\
TS $\times$ Time & $3.205^{*}$ & $3.179^{*}$ & $4.572^{*}$ \\
\hline
\end{tabular}

Note. $*$ Significant at $5 \%$, by analysis of variance; TS-Seed treatment. 
The mean plant height (AP) dynamics, for the cultivation of soybean cv. 'FTS Paragominas RR', according to the treatments analyzed, for periods and between periods of estimation (unfolding), is presented in Table 2.

Table 2. Interaction of seed treatment $\times$ time, for plant height of the soybean crop, at 35,50 and 65 days after sowing

\begin{tabular}{llll}
\hline \multirow{2}{*}{ Seed Treatment } & \multicolumn{3}{c}{ Plant height $(\mathrm{cm})$} \\
\cline { 2 - 4 } & $35 \mathrm{DAS}$ & $50 \mathrm{DAS}$ & $65 \mathrm{DAS}$ \\
\hline Thiophanate-methyl + fluazinam & $35.72 \mathrm{ABb}$ & $47.57 \mathrm{Ba}$ & $51.07 \mathrm{Ba}$ \\
Fludioxonil & $38.70 \mathrm{Ab}$ & $56.40 \mathrm{Aa}$ & $59.00 \mathrm{Aa}$ \\
Carbendazim + thiram & $31.60 \mathrm{BCc}$ & $37.05 \mathrm{Db}$ & $46.00 \mathrm{Ca}$ \\
Fipronil & $30.02 \mathrm{Cc}$ & $41.70 \mathrm{CDb}$ & $45.77 \mathrm{Ca}$ \\
Control & $31.10 \mathrm{BCb}$ & $43.90 \mathrm{BCa}$ & $46.70 \mathrm{BCa}$ \\
\hline DMS $_{1}$ (TS) & $\mathrm{DMS}_{2}$ (Time) & $\mathrm{CV}_{1}(\mathrm{TS})$ & $\mathrm{CV}_{2}(\mathrm{Time})$ \\
4.719 & 3.718 & 10.14 & 5.95 \\
\hline
\end{tabular}

Note. Means followed by equal letters, capitals in the columns and lowercase in the rows, do not differ by the $\mathrm{t}$ test at 5\% significance; $\mathrm{DMS}_{1}$ (TS) and $\mathrm{DMS}_{2}$ (Time)-Minimum significant difference for seed treatment and time, respectively; $\mathrm{CV}_{1}$ (TS) and $\mathrm{CV}_{2}$ (Time)-Coefficient of variation (\%) for treatment of seed and time, respectively.

At the initial stage of development, after 35 DAS, it was observed that the soybean seeds treated with the active ingredients fludioxonil (dose, $200 \mathrm{~mL}$ per $100 \mathrm{~kg}$ of seeds), both fungicides, produced plants with higher average height ( 38.70 and $35.72 \mathrm{~cm}$, respectively) and statistically equivalent to each other. However, the insecticide based on fipronil (dose, $200 \mathrm{~mL}$ per $100 \mathrm{~kg}$ of seeds) induced a lower size $(30.02 \mathrm{~cm}$ ) and similar to the fungicide carbendazim + thiram (Table 2).

For a period of 50 days after sowing, similarly to the previous measurement, the use of fludioxonil excelled between the others, with a plant height of $56.40 \mathrm{~cm}$, on average (Table 2). Whereas, the active ingredient insecticide fipronil and the control treatment, represented the intermediate performance, with statistical similarity. At 65 days from sowing, again, beneficial influence for the size of plants from the application of the active product fludioxonil was measured, mean of $59.00 \mathrm{~cm}$, differing from the remaining treatments $(\mathrm{p}<0.05)$, (Table 2).

In agreement with the initial evaluations, it was noted worst yields high, for the use of fipronil and carbendazim + thiram. Inhibitory effects of seed treatment are also reported in the literature. Dan et al. (2012) observed symptoms of phytotoxicity for soybean plants, at 30 days after sowing, the occurrence of seeds treated with insecticides, which resulted in a significant reduction in the average height of the crop.

Menten and Moraes (2010) advocated the mixing of fungicides of different modes of action, in order to increase the number of targets to be controlled and resistance management prolonging the lifetime of the assets. However, the combination of carbendazim + thiram $(200 \mathrm{~mL}$ of p.a. to $100 \mathrm{~kg}$ of seeds $)$ culminated in a phytotoxic effect on soybean growth at 50 DAS, with the lowest average $(37.05 \mathrm{~cm})$, underlying the absence of application $(\mathrm{p}<0.05)$. Similar to what occurred in the present study.

Nonogaki et al. (2010) explained that seed treatment promotes increases in germination and plant growth, due to the improvement of the enzymatic activity and smooth functioning of the cell membranes that are indispensable for the germination, as well as they interfere with the synthesis and degradation compounds for the mobilization of reserves, as well as expansion, cell division and growth, occurring during germination. In this context, the use of doses and inadequate mixtures may culminate in unexpected negative effects, similar was reported for some tested active principles in relation to plant height.

Pereira et al. (2009), reported that thiophanate-methyl had a detrimental effect on the percentage of emergence, index of emergence speed and height of soybean plants, which contradicts the observations of the present study.

The mean diameter of the stem (DC), for the plants originating from the seeds submitted to the contact of the phytosanitary products studied, unfolding between time and seed treatment, are shown in Table 3. 
Table 3. Interaction seed treatment $\mathrm{x}$ time, for the variable stem diameter of the soybean crop at 35,50 and 65 days after sowing

\begin{tabular}{llll}
\hline \multirow{2}{*}{ Seed Treatment } & \multicolumn{3}{c}{ Stem Diameter $(\mathrm{mm})$} \\
\cline { 2 - 4 } & $35 \mathrm{DAS}$ & $50 \mathrm{DAS}$ & $65 \mathrm{DAS}$ \\
\hline Thiophanate-methyl + fluazinam & $7.42 \mathrm{ABa}$ & $8.27 \mathrm{ABa}$ & $8.22 \mathrm{Ba}$ \\
Fludioxonil & $7.40 \mathrm{Ba}$ & $7.02 \mathrm{Ca}$ & $8.17 \mathrm{Ba}$ \\
Carbendazim + thiram & $7.50 \mathrm{ABa}$ & $7.57 \mathrm{BCa}$ & $8.67 \mathrm{Ba}$ \\
Fipronil & $8.55 \mathrm{Ab}$ & $9.22 \mathrm{Aab}$ & $10.30 \mathrm{Aa}$ \\
Control & $7.25 \mathrm{Ba}$ & $4.62 \mathrm{Db}$ & $7.65 \mathrm{Ba}$ \\
DMS $_{1}$ (TS) & $\mathrm{DMS}_{2}(\mathrm{Time})$ & $\mathrm{CV}_{1}(\mathrm{TS})$ & $\mathrm{CV}_{2}$ (Time) \\
1.138 & 1.239 & 8.43 & 10.81 \\
\hline
\end{tabular}

Note. Means followed by equal letters, capitals in the columns and lowercase in the rows, do not differ by the $\mathrm{t}$ test at $5 \%$ significance; $\mathrm{DMS}_{1}$ (TS) and $\mathrm{DMS}_{2}$ (Time)-Minimum significant difference for seed treatment and time, respectively; $\mathrm{CV}_{1}$ (TS) and $\mathrm{CV}_{2}$ (Time)-Coefficient of variation (\%) for treatment of seed and time, respectively.

At 35 days after sowing, it was verified that plants whose seeds were treated with the insecticide fipronil (dose, 200 $\mathrm{mL}$ for $100 \mathrm{~kg}$ of seeds) and the fungicides carbendazim + thiram $(200 \mathrm{~mL}$ for $100 \mathrm{~kg}$ of seeds) and methyl thiophanate + fluazinam (dose, $198 \mathrm{~mL}$ per $100 \mathrm{~kg}$ of seeds), presented the highest means of stem diameter (8.55, 7.50 and $7.42 \mathrm{~mm}$, respectively), which did not differ statistically from each other. The absence of treatment was inferior to all active principles tested $(7.25 \mathrm{~mm})$.

The subsequent computation (50 DAS) corroborated with the previous and related the insecticide fipronil to plants with a higher diameter $(9.22 \mathrm{~mm})$ and analogous to the fungicide thiophanate-methyl + fluazinam, mean of 8.27 $\mathrm{mm}$ (Table 3). The control was negatively differentiated from the tested pesticides, with a mean diameter of 4.62 $\mathrm{mm}$.

These results diverge with Cunha et al. (2015), who did not report changes in stem diameter, when assessing the effect of treatment of soybean seeds with fludioxonil, thiophanate-methyl and fipronil at 15, 30 and 45 days after emergence.

After 65 days from sowing, it was also observed that the application of fipronil resulted in plants with a greater thickness $(10.30 \mathrm{~mm})$. The lowest absolute response occurred for the absence of an application, whose mean was 7 . These results diverge with Masson et al. (2015) who did not notice statistical differences for stem diameter when investigating the efficacy of insecticide application in the treatment of soybean seeds. Possibly, this occurred due to the phenological phase (R3) analyzed by the authors, in which the effects of the active principles can be omitted, in relation to the initial startup.

In relation to estimates during the vegetative growth, i.e., among the regular periods, there was a significant increase in stem diameter only for the insecticide fipronil and only between 35 and 65 DAS. The control showed a decrease to 50 DAS, with statistical significance. The treatments with Thiophanate-methyl + fluazinam, fludioxonil, and carbendazim + thiram did not respond to the action of the active principles, for the stem diameter, between periods of measurements $(p>0.05)$ (Table 3$)$. Therefore, the results indicate that the insecticide presented a greater effect on stem horizontalization, while the fungicides expressed greater interference on the verticalization.

In Table 4 are presented the means obtained for the foliar area (FA) of the soybean 'FTS Paragominas RR', resulting from the different seed treatments (TS), throughout the crop cycle, by and between periods of measurements (unfolding) estimated through Image ${ }^{\mathbb{R}}$ and digital imaging assumptions. 
Table 4. Interaction seed treatment plot $\times$ time, for the variable leaf area of the soybean crop at 35,50 and 65 days after sowing

\begin{tabular}{llll}
\hline \multirow{2}{*}{ Seed Treatment } & \multicolumn{3}{c}{ Leaf Area $\left(\mathrm{cm}^{2}\right)$} \\
\cline { 2 - 4 } & $35 \mathrm{DAS}$ & $50 \mathrm{DAS}$ & $65 \mathrm{DAS}$ \\
\hline Thiophanate-methyl + fluazinam & $53.70 \mathrm{Aa}$ & $40.82 \mathrm{BCb}$ & $36.92 \mathrm{ABb}$ \\
Fludioxonil & $45.80 \mathrm{Bb}$ & $51.62 \mathrm{Aa}$ & $40.30 \mathrm{Ab}$ \\
Carbendazim + thiram & $45.07 \mathrm{Ba}$ & $39.90 \mathrm{BCa}$ & $31.92 \mathrm{Bb}$ \\
Fipronil & $44.27 \mathrm{Ba}$ & $41.27 \mathrm{Ba}$ & $42.47 \mathrm{Aa}$ \\
Control & $40.45 \mathrm{Ba}$ & $34.80 \mathrm{Cab}$ & $32.37 \mathrm{Bb}$ \\
\hline DMS $_{1}(\mathrm{TS})$ & $\mathrm{DMS}_{2}(\mathrm{Time})$ & $\mathrm{CV}_{1}(\mathrm{TS})$ & $\mathrm{CV}_{2}$ (Time) \\
6,394 & 5.696 & 12.95 & 9.42 \\
\hline
\end{tabular}

Note. Means followed by equal letters, capitals in the columns and lowercase in the rows, do not differ by the $\mathrm{t}$ test at $5 \%$ significance; $\mathrm{DMS}_{1}$ (TS) and $\mathrm{DMS}_{2}$ (Time)-Minimum significant difference for seed treatment and time, respectively; $\mathrm{CV}_{1}$ (TS) and $\mathrm{CV}_{2}$ (Time)-Coefficient of variation (\%) for treatment of seed and time, respectively.

The leaf area (AF) represents the light interception apparatus for photosynthesis and is a characteristic used in analyzes of plant growth (Cunha et al., 2010). It is essential for the production of carbohydrates, lipids and proteins by the plant (Coelho et al., 2010). In this sense, the leaf area of a culture allows to infer about the photosynthetic potential, besides being widely known to be a parameter indicative of Productivity (Zeist et al., 2014).

The results indicated that the use of active ingredient fungicide thiophanate-methyl + fluazinam (198 $\mathrm{mL}$ dose), provided the highest leaf yield at $35 \mathrm{DAS}$, with a value of $53.70 \mathrm{~cm}^{2}$, a significant difference from the others. The control measured the lowest absolute leaf surface $\left(40.45 \mathrm{~cm}^{2}\right)$.

Based on the larger leaf surface, it is assumed that plants originated from seeds treated with the active product thiophanate-methyl + fluazinam, would present greater accumulation of photoassimilates to invest in the own vegetative growth and, posteriorly, translocate them for grain production, according to each phenological stage of the crop and source-drain relationship.

At 50 DAS, opposing the initial analysis, the fungicide fludioxonil base, at a dose of $200 \mathrm{~mL}$ per $100 \mathrm{~kg}$ of seed, provided a leaf area superior to the others $(\mathrm{p}<0.05)$, with a mean surface area of $51.62 \mathrm{~cm}^{2}$. The absence of application quantified the lowest estimate $\left(34.80 \mathrm{~cm}^{2}\right)$, together with the active product carbendazim + thiram $\left(39.90 \mathrm{~cm}^{2}\right)$, statistically analogous.

The posterior measurements (65 DAS) of 'FTS Paragominas RR' soybean indicated that the application of the active product insecticide fipronil $(200 \mathrm{~mL}$ dose $)$ induced a higher absolute leaf area $\left(42.47 \mathrm{~cm}^{2}\right)$, followed by fludioxonil and thiophanate-methyl + fluazinam (all statistically equivalent to each other). The fungicide carbendazim + thiram (dose $200 \mathrm{~mL}$ ) evidenced the lowest average leaf yield $\left(31.92 \mathrm{~cm}^{2}\right)$, but did not differ statistically from the absence of treatment $\left(32.37 \mathrm{~cm}^{2}\right)$.

With reference to the experimental accuracy of the scientific, it was found variability (by evaluation season) of $12.95 \%$, slightly above average for agronomic characteristics plant height and stem diameter.

Among leaf area evaluations, it was observed a significant reduction for almost all seed treatments, to the restriction of treatment with fipronil insecticide (Table 4). According to Silva (2001), the decrease of leaf area helps in the knowledge of the source-drain relation and translates into immediate practical results, such as evaluation of grain yield, yield effect with anticipated harvesting, simulation of pest or disease attack, and damage caused by hail.

In absolute terms, between 35 and 65 DAS the fungicide thiophanate-methyl + fluazinam promoted a more expressive decrease $\left(16.78 \mathrm{~cm}^{2}\right)$. Followed by carbendazim + thiram, which estimated reduction of $13.15 \mathrm{~cm}^{2}$, in the mentioned period. The insecticide fipronil estimated decline of only $1.8 \mathrm{~cm}^{2}$ and not significant by the test at 5\%. Monteiro et al. (2005) Affirmed that the value of AF depends on the number and size of the leaves and their residence time in the plant, that is, it will vary throughout the crop cycle.

In this study, the reduction of leaf area is associated to the reproductive phase, in which the plants destine the photoassimilates for flowers, fruits and seeds, defined as strong drains. 
The estimated agronomic characteristics at the time of harvest as well as the summary of the analysis of variance are presented in Table 5. Except for grain production $(\mathrm{P})$, significant responses to height of first pod insertion (AIPV), total number of pods (NTV) and weight of 1000 grains (PMG) were observed.

Table 5. Height of first pod insertion (AIPV), total number of pods (NTV), weight of 1000 grains (PMG) and grain yield $(\mathrm{P})$ of soybean according to different seed treatments

\begin{tabular}{lllll}
\hline \multirow{2}{*}{ Seed Treatment } & \multicolumn{3}{c}{ Variables } \\
\cline { 2 - 5 } & AIPV $(\mathrm{cm})$ & NTV & PMG $(\mathrm{g})$ & $\mathrm{P}\left(\mathrm{kg} \mathrm{ha}^{-1}\right)$ \\
\hline Thiophanate-methyl + fluazinam & $8.09 \mathrm{bc}$ & $1773.00 \mathrm{ab}$ & $137.70 \mathrm{a}$ & $3488.20 \mathrm{a}$ \\
Fludioxonil & $11.80 \mathrm{a}$ & $2176.25 \mathrm{a}$ & $132.42 \mathrm{a}$ & $3507.80 \mathrm{a}$ \\
Carbendazim + thiram & $8.52 \mathrm{~b}$ & $1383.00 \mathrm{~b}$ & $115.87 \mathrm{~b}$ & $3675.80 \mathrm{a}$ \\
Fipronil & $6.19 \mathrm{c}$ & $1372.75 \mathrm{~b}$ & $130.27 \mathrm{a}$ & $3115.82 \mathrm{a}$ \\
Control & $9.41 \mathrm{~b}$ & $1608.00 \mathrm{~b}$ & $133.90 \mathrm{a}$ & $3625.50 \mathrm{a}$ \\
\hline DMS & 1.962 & 412.268 & 7.714 & 1165.322 \\
CV (\%) & 14.47 & 16.09 & 3.85 & 21.72 \\
\hline Sources of Variation & Calculated F & & \\
Seed Treatment & $10.318^{*}$ & $6.161^{*}$ & $11.167^{*}$ & $0.337^{\mathrm{ns}}$
\end{tabular}

Note. Means followed by equal letters in the columns do not differ from each other, by the t test at $5 \%$ significance; DMS-Minimum Significant Difference; CV-Coefficient of Variation (\%); * Significant at 5\%; and ${ }^{\text {ns }}$ not significant at $5 \%$, by analysis of variance.

According to Braz et al. (2010), the evaluation of the height of first pod insertion in soybean is essential because it influences productivity. It is assumed that the lower the AIPV, the greater are the potential of yield losses at the time of mechanized harvesting because the cutting platform of the harvester operates at minimum ground height. For this variable, it was observed that the dose of $200 \mathrm{~mL}$ per $100 \mathrm{~kg}$ of seeds of the active ingredient fludioxonil, promoted a larger increase $(11.80 \mathrm{~cm})$. The insecticide fipronil, in turn, quantified the lowest mean $(6.19 \mathrm{~cm})$ and characterized an adverse effect for the variable, since it is significantly below control.

Pereira Júnior et al. (2010) correlated this agronomic characteristic to the flow of harvested material and affirmed that the normal standards for height of the cut bar in the mechanical harvesting of soybeans, is positioned around $15 \mathrm{~cm}$. Chioderoli et al. (2012) observed AIPV of $14 \mathrm{~cm}$ and also reported that it is an adequate measure.

Therefore, except with the application of fludioxonil, all values moved away from ideal and, if mechanical harvesting were performed, could lead to excessive losses, due to uncollected pods. This may have occurred at the time of climatic adversities during the conduct of the experiment, which may have led to higher precocity of the crop. In this case, to improve crop yield, the harvester's cutting platform should be adjusted to work more closely to the ground.

For the total number of pods (NTV), the application of the fungicide fludioxonil was positively differentiated from the control $(\mathrm{p}<0.05)$, with an increase of $35.34 \%$, and reached 2176.25 pods. Treatment with a formulated fungicide of thiophanate-methyl + fluazinam equaled to the best performance, as well as to the others. Amponsah et al. (2012) studied the efficacy of fourteen fungicides of different active ingredients, tested in vitro with a range of concentrations for disease management, and reported that thiophanate-methyl was more effective overall.

The coefficient of variation was $16.09 \%$. Bertolin et al. (2010) evaluated soybean yield as a function of the application of biostimulants, the authors verified CV of $12.2 \%$ for the total number of pods. While Cato and Castro (2006) have evidenced greater variability (35.5\%), for the same agronomic character. Therefore, the instability of the present study corroborates with the limits described in the literature.

Regarding the weight of 1000 grains, it was observed that the fungicide carbendazim + thiram presented phytotoxicity $(115.87 \mathrm{~g})$ and differed statistically from the absence of treatment. The remaining treatments responded in a similar way, close in a module and similar to each other, according to the Student t-test.

According to Thomas and Costa (2010), a yield of grain weight represents the grain size and, therefore, presents the characteristic value of each cultivar, but this does not prevent it from varying according to the environmental and management conditions to which the crop is submitted.

In this regard, according to Table 5, it was found that none of the evaluated products yielded increases in grain yield $(\mathrm{P})$ in soybean plants $(\mathrm{p}>0.05)$. Therefore, the final product is the same for all tested ingredients. 
These results corroborate with Cunha et al. (2015), who observed that any of the tested fungicides and insecticides provided increases in grain yield in soybean plants. Balardin et al. (2011) treated soybean seeds with fungicides and insecticides and found that productivity was not influenced in a regime without water stress. Only in the presence of water deficit, there was a difference between them, where the largest increase corresponded to treatments with fipronil + thiophanate-methyl + pyraclostrobin and abamectin + thiamethoxam + fludioxonil + mefenoxam + thiabendazole.

Although the active fludioxonil product has expressed a high number of pods, it was not reflected in a higher increase to the others for the components, weight of 1000 grains and productivity, in terms of the module. Whereas the carbendazim + thiram compound produced NTV numerically below the control, impaired PMG and increased absolute grain yield $(\mathrm{P})$.

It is emphasized that the occurrence of dried or empty pods, as well as the number of grains per pod, directly influence the soybeans production. According to Lima et al. (2009), the fixed pods of legumes may become empty due to problems in fertilizing the eggs inside the ovary or due to the lack of carbohydrates essential for the filling of the grains, reflecting in lower yields.

Thus, it is understood that some climatic adversities, especially water stress due to the low rainfall rates, occurred during the experiment conduction, may have culminated in the absence of productivity gains in the parcels that received seed treatment, as well as inadequate management practices.

Although high leaf area for thiophanate-methyl + fluazinam in the first analysis (35 DAS), as well as a substantial reduction $\left(16.78 \mathrm{~cm}^{2}\right)$ in a final evaluation $(65 \mathrm{DAS})$, this result was not reflected in higher numerical productivity gain $\left(3488.20 \mathrm{~kg} \mathrm{ha}^{-1}\right)$.

Since this technology does not always result in protection of the plants during the entire vegetative period (Azevedo et al., 2004), the pests in soybean plantations can cause reductions in photosynthesis, stomatal driving, transpiration and, also, lead to foliar senescence (Gamundi \& Perotti, 2016). As photosynthesis depends on the leaf area (AF), the yield of the crop will be higher the faster the plant reaches the maximum leaf surface and the longer the AF remains active (Manfron et al., 2003).

Although the fungicide carbendazim + thiram had presented a decline in leaf area $\left(13.15 \mathrm{~cm}^{2}\right)$ immediately below thiophanate-methyl + fluazinam, this expressed higher productivity modulus $\left(3675.80 \mathrm{~kg} \mathrm{ha}^{-1}\right)$. Accordingly, Mertz et al. (2009), infer that the fungicides of the benzimidazoles group are the most suitable for the treatment of seeds because they are more efficient in the fungi control, with significance on the active principles, carbendazim, thiophanate methyl, and thiabendazole. In California, Rolshausen et al. (2010) investigated the efficacy of four fungicides in the prevention of vine infection in the field by nine inoculated fungi. The authors reported a lesser infestation for control with methyl thiophanate. $\mathrm{Li}$ and $\mathrm{Mu}$ (1995) also recommended the use of methyl thiophanate and carbendazim by significantly reducing the development of B. dothidea and L. theobromae in apricot trees in Japan.

For seed plants treated with the insecticide fipronil, with a non-significant AF decrease $\left(1.80 \mathrm{~cm}^{2}\right)$, the lowest grain yield, $3115.82 \mathrm{~kg} \mathrm{ha}^{-1}$, was observed. Mundstock and Thomas (2005) explained that an imbalance in the nutrition relationship between leaves and vegetables, called "leaf retention", can be triggered by several causes and symptoms. Leaves and stems of stalk and branches remain green, without getting into senescence when the vegetables (grains) are already formed. One of the most common causes is the presence of insects (bedbugs, in particular), which absorb the sap and inject toxins or another agent (virus), which inhibits the onset of leaf senescence.

To sum up, the results indicated that the effects of the fungicides and insecticides used for the treatment of soybean are variable, according to the evaluation phases and agronomic characteristics evaluated. As well as, it was realized that mass gains in the growth phase are not guarantees of higher yields and better quality of grains because the climatic conditions and the management of the culture can interfere in this merit. In this sense, it is recommended to adopt seed treatment, as a preventive practice of phytosanitary problems and stimulant to the growth of plants, in the initial phase.

However, appropriate doses and active principles should be selected for each producing region. In the present study, the best yields were obtained with thiophanate-methyl + fluazinam (dose $198 \mathrm{~mL}$ ) and fludioxonil (dose 200 $\mathrm{mL})$. 


\section{Conclusions}

The use of different seed treatments promoted fairly variable responses in the growth and development of the 'FTS Paragominas RR' soybean crop. In general, the best yields were obtained using fungicides with thiophanate-methyl + fluazinam (dose $198 \mathrm{~mL}$ ) and fludioxonil (dose $200 \mathrm{~mL}$ ).

The application of carbendazim + thiram and fipronil, both at the dose of $200 \mathrm{~mL}$, s should be viewed with an exception for registering adverse responses throughout the soybean cycle 'FTS Paragominas RR'.

\section{Acknowledgements}

To Agroverdes Comércio and Representação Agrícola LTDA-EPP, as well as the rural producers Tiago Fernando Riewe Tomm and Jonathan Alex Deifeld for the availability of agricultural inputs needed to conduct the research.

\section{References}

Amponsah, N. T., Jones, E. E., Ridgway, H. J., \& Jaspers, M. V. (2012). Evaluation of fungicides for the management of Botryosphaeria dieback diseases of grapevines. Pest Manag. Sci., 68, 676-683. https://doi.org/10.1002/ps.2309

Artuzo, F. D., Foguesatto, C. R., Souza. Â. R. L., \& Silva, L. X. (2018). Gestão de custos na produção de milho e soja. Rev. Bras. Gest. Neg,, 20(2), 273-294. https://doi.org/10.7819/rbgn.v20i2.3192

Azevedo, R., Grützmacher, A. D., Loeck, A. E., Silva, F. F., Storch, G., \& Herpich, M. L. (2004). Efeito do tratamento de sementes e aplicações foliares de inseticidas em diferentes volumes de calda, no controle de Spodoptera frugiperda (J.E. Smith, 1797) (Lepidoptera: Noctuidae), nas culturas do milho e sorgo em agroecossistema de várzea. Revista Brasileira de Agrociência, 10, 71-77.

Balardin, R. S., Silva, F. D. L., Debona, D., Corte, G. D., Favera, D. D., \& Tormen, N. R. (2011). Tratamento de sementes com fungicidas e inseticidas como redutores dos efeitos do estresse hídrico em plantas de soja. Ciência Rural, 41(7), 1120-1126. https://doi.org/10.1590/S0103-84782011000700002

Bertolin, D. C., Sá, M. E., Orivaldo, A. R. F., Furlani Junior, E., Colombo, A. S., \& Carvalho, F., L., B. (2010). Aumento da produtividade de soja com a aplicação de bioestimulantes. Bragantia, 69(2), 339-347. https://doi.org/10.1590/S0006-87052010000200011

Braz, G. B. P., Cassol, G. M., Ordonez, G. A. P., Simon, G. A., Procópio, S. O., Oliveira Neto, A. M.,... Dan, H. A. (2010). Componentes de produção e rendimento de soja em função da época de dessecação e do manejo em pós-emergência. Revista Brasileira de Herbicidas, 9(2), 63-72. https://doi.org/10.7824/rbh.v9i2.83

Buzzerio, N. F. (2010). Ferramentas para qualidade de sementes no tratamento de sementes profissional. Informativo: Revista Brasileira de Sementes, 20(3), 56.

Carvalho, C., \& Novembre, A. D. L. C. (2011). Avaliação da qualidade de sementes de fumo, nuas e revestidas, pelo teste de condutividade elétrica. Revista Brasileira de Sementes, 33, 177-185. https://doi.org/10.1590/ S0101-31222011000100020

Cato, S. C., \& Castro, P. R. C. (2006). Redução da altura de plantas de soja causada pelo ácido 2,3,5-triiodobenzóico. Ciência Rural, 36(3), 981-984. https://doi.org/10.1590/S0103-84782006000300041

Chioderoli, C. A., Silva, R. P., Noronha, R. H. F., Cassia, M. T., \& Santos, E. P. (2012). Perdas de grãos e distribuição de palha na colheita mecanizada de soja, 71(1), 112-121. https://doi.org/10.1590/S0006-8705 2012005000003

Coelho, J. M., Resende, L. V., Resende, J. T. V., Rolim Neto, F. C., \& Jimenez, H. J. (2010). Caracterização topográfica de folíolos medianos de cultivares de morangueiro sob altas temperaturas. Revista Caatinga, 3(3), 13-18.

CONAB (Companhia Nacional de Abastecimento). (2018). Acompanhamento da Safra Brasileira de Grãos. Safra 2017/18 (Décimo Levantamento, 10, p. 17).

Cunha, J. L. X. L., Nascimento, P. G. M. L., Mesquita, H. C., Silva, M. G. O., Dollabona, J. L. D., \& Silva, I. N. (2010). Comparação de métodos de área foliar em Chrysobalanus icaco L. Agropecuária Científica no Semi-Árido, 6(3), 22-27.

Cunha, R. P., Corrêa, M. F., Schuch, L. O. B., Oliveira, R. C., Abreu Júnior, J. S., Silva, J. S. G., \& Almeida, T. L. (2015). Diferentes tratamentos de sementes sobre o desenvolvimento de plantas de soja. Ciência Rural, 45(10), 1761-1767. https://doi.org/10.1590/0103-8478cr20140742 
Dan, L. G. M., Dan, H. A., Barroso, A. L. L., \& Braccini, A. L. (2010). Qualidade fisiológica de sementes de soja tratadas com inseticidas sob efeito do armazenamento. Revista Brasileira de Sementes, 32(2), 131-139. https://doi.org/10.1590/S0101-31222010000200016

Dan, L. G. M., Dan, H. A., Piccini, G. G., Ricci, T. T., \& Ortiz, A. H. T. (2012). Tratamento de sementes com inseticida e a qualidade fisiológica de sementes de soja. Revista Caatinga, 25(1), 45-51.

EMBRAPA. (1999). Empresa Brasileira de Pesquisa Agropecuária Centro Nacional de Pesquisa de Solos (p. 421). Sistema Brasileiro de Classificação de Solos: EMBRAPA Solos.

Ferreira, D. F. (2008). Sisvar: Um programa para análises e ensino de estatística. Revista Symposium, 6(2), 36-41.

França-Neto, J. B., Krzyzanowski, F. C., Henning, A. A., Pádua, G. P., Lorini, I., \& Henning, F. A. (2016). Tecnologia da produção de semente de soja de alta qualidade. Embrapa Soja (p. 82).

FTS Sementes. (2009). Cultivar FTS Paragominas RR. Retrieved January 3, 2019, from http://ftsementes.com.br

Gamundi, J. C., \& Perotti, E. (2016). Evaluación de daño de Frankliniella schultzei (Trybom) y Caliothrips phaseoli (Hood) en diferentes estados fenológicos del cultivo de soja. Para Mejorar la Produción, 42(1), 107-111.

Henten, E. J., \& Bontsema, J. (1995). Non-destructive crop measurements by image processing for crop growth control. Journal of Agricultural Engineering Research, 61(2), 97-105. https://doi.org/10.1006/jaer.1995. 1036

Hirakuri, M. H., \& Lazzarotto J. J. (2014) O agronegócio da soja nos contextos mundial e brasileiro. Documentos, 349, 1-70.

IBGE (Instituto Brasileiro de Geografia e Estatística). (2012). Manual técnico da vegetação brasileira (2nd ed., p. 271). Coordenação de Recursos Naturais e Estudos Ambientais, Diretoria de Geociências, Rio de Janeiro.

Korber, A. H. C., Pinto, L. P., Pivetta, L. A., Albrecht, L. P., \& Frigo, K. D. A. (2017). Adubação nitrogenada e potássica em soja sob sistemas de semeadura. Revista de Agricultura Neotropical, 4(4), 38-45. https://doi.org/10.32404/rean.v4i4.1653

Leal, A. J. F., Valderrama, M., Kaneko, F. H., Leal, U. A. S., Perin, A., \& Luchese, K. U. O. (2015). Produtividade da soja de acordo com diferentes doses de cloreto de potássio revestido ou não com polímeros. Global Science and Technology, 08(01), 19-30. https://doi.org/10.14688/1984-3801/ gst.v8n1p19-30

Li, H. Y., Cao, R. B., \& Mu, Y. T. (1995). In vitro inhibition of B. dothidea and L. theobromae, and chemical control of gummosis disease of Japanese apricot and peach trees in Zhejiang Province. Crop Prot, 14(1), 187-191. https://doi.org/10.1016/0261-2194(95)00011-A

Lima, E., Do, V., Crusciol, C. A. C., Cavariani, C., \& Nakagawa, J. (2009). Características agronômicas, produtividade e qualidade fisiológica da soja "safrinha" sob semeadura direta, em função da cobertura vegetal e da calagem superficial. Revista Brasileira de Sementes, 31(1), 070-079. https://doi.org/10.1590/ S0101-31222009000100008

Manfron, P. A., Dourado Neto, D., Pereira, A. R., Bonnecarrère, R. A. G., Medeiros, S. L. P., \& Pilau, F. G. (2003). Modelo do índice de área foliar da cultura do milho. Revista Brasileira de Agrometeorologia, 11(2), 333-342.

Marcon, E. C., Romio, S. C., Maccari, V. M., Klein, C., \& Lájus, C. R. (2017). Uso de diferentes fontes de nitrogênio na cultura da soja. Revista Thema, 14(2), 298-308.

Masson, G. L., Colman, B. A., Fuentes, L. F. G., Schwerz, F., \& Trindade, R. B. R. (2015). Eficácia da aplicação de inseticidas no tratamento de sementes de soja e seus efeitos no desenvolvimento inicial da cultura. Enciclopédia Biosfera, Centro Científico Conhecer, 11(21), 922.

Menten, J. O. M., \& Moraes, M. H. D. (2010). Tratamento de sementes: Histórico, tipos, características e benefícios. Informativo Abrates, 20(3), 52-53

Mertz, L. M., Henning, F. A., \& Zimmer, P. D. (2009). Bioprotetores e fungicidas químicos no tratamento de sementes de soja. Ciência Rural, 39(1). https://doi.org/10.1590/S0103-84782009000100003 
Monteiro, J. E. B. A., Sentelhas, P. C., Chiavegato, E. J., Guiselini, C., Santiago, A. V., \& Prela, A. (2005). Estimação da área foliar do algodoeiro por meio de dimensões e massa das folhas. Bragantia, 64(1), 15-24. https://doi.org/10.1590/S0006-87052005000100002

Mundstock, C. M., \& Thomas, A. L. (2005). Soja: Fatores que afetam o crescimento e o rendimento de grãos. Departamento de Plantas de Lavoura da Universidade Federal do Rio Grande do Sul: Evangraf.

Nonogaki, H., Bassel, G. W., \& Bewley, J. D. (2010). Germination-Still a mystery. Plant Science, 179(6), 574-581. https://doi.org/10.1016/j.plantsci.2010.02.010

Passos, M. L. V., Zambrzycki, G. C., \& Pereira, R. S. (2016). Balanço hídrico e classificação climática para uma determinada região de Chapadinha-MA. Revista Brasileira de Agricultura Irrigada, 10(4), 758-766. https://doi.org/10.7127/rbai.v10n400402

Peixoto, S. A., Ribeiro, F. W., Rodrigues, C. C., Silva, A. C., \& Araujo, M. S. (2018). Estudo Econômico do Cultivo de Soja dom Safrinha de Milho e Girassol. Enciclopédia Biosfera, Centro Científico Conhecer, 15(27), 254-264. https://doi.org/10.18677/EnciBio_2018A47

Pereira Júnior, P., Rezende, P. M., Malfitano, S. C., Lima, R. K., Corrêa, L. V. T., \& Carvalho, E. R. (2010). Efeito de doses de silício sobre a produtividade e características agronômicas da soja [Glycine max (L.)]. Ciência e Agrotecnologia, 34(4), 908-913. https://doi.org/10.1590/S1413-70542010000400016

Pereira, C. E., Oliveira, J. A., Rosa, M. C. M., Oliveira, G. E., \& Costa Neto, J. (2009). Tratamento fungicida de sementes de soja inoculadas com Colletotrichum truncatum. Ciência Rural, 39(9), 2390-2395. https://doi.org/10.1590/S0103-84782009005000215

Petter, F. A., Alves, A. U., Silva, J. A., Cardoso, E. A., Alixandre, T. F., Almeida, F. A., \& Pacheco, L. P. (2014). Produtividade e qualidade de sementes de soja em função de doses e épocas de aplicação de potássio. Semina: Ciências Agrárias, 35(1), 89-100. https://doi.org/10.5433/1679-0359.2014v35n1p89

Reges, R. S. (2018). Efeito de doses de herbicida e tipos de inoculantes na cultura da soja FTS Paragominas no município de Areia-PB. Rayan Sabino Reges, Areia, PB: UFPB/CCA.

Rolshausen, P. E., Urbez-Torres, J. R., Rooney-Latham, S., Eskalen, A., Smith, R. J., \& Gubler, W. D. (2010). Evaluation of pruning wound susceptibility and protection against fungi associated with grapevine trunk diseases. Am J Enol Vitic, 61(1), 113-119.

Schoeninger, V., \& Bischoff, T. Z. (2014). Tratamento de sementes. Journal of Agronomic Sciences, 3(Especial), 63-73.

Silva, P. S. L. (2001). Desfolha e supressão da frutificação em milho. Revista Ceres, 48(275), 55-70.

Thomas, A. L., \& Costa, J. A. (2010). Desenvolvimento da planta de soja e potencial de rendimento de grãos. In A. L. Thomas, \& J. A. Costa (Eds.), Soja: manejo para alta produtividade de grãos. Porto Alegre: Evangraf.

Zeist, A. R., Oliveira, J. R. F., Lima Filho, R. B., Silva, M. L. S., \& Resende, J. T. V. (2014). Comparação de métodos de estimativa de área foliar em morangueiro. Pesquisa Agropecuária Gaúcha, 20(1/2), 33-41.

\section{Copyrights}

Copyright for this article is retained by the author(s), with first publication rights granted to the journal.

This is an open-access article distributed under the terms and conditions of the Creative Commons Attribution license (http://creativecommons.org/licenses/by/4.0/). 